\title{
POLA PERMUKIMAN DI SEKITAR SITUS BERSEJARAH GIRI KEDATON
}

\author{
Firdha Ayu Atika1* \\ ${ }^{1}$ Arsitektur, Fakultas Teknik Sipil dan Perencanaan, Institut Teknologi Adhi Tama Surabaya, \\ Jl. Arief Rachman Hakim 100 Surabaya, 60117 \\ *firdhayu@itats.ac.id
}

\begin{abstract}
ABSTRAK
Situs Giri Kedaton merupakan salah objek wisata bernilai historis di Kabupaten Gresik. Akan tetapi keberadaannya kurang dikenal oleh wisatawan. Salah satu penyebabnya adalah kurangnya daya dukung permukiman disekitar Situs Giri Kedaton yang mampu mendukung nilai historis kawasan. Sehingga perlu dilakukan penelitian ini untuk mengetahui pola permukiman yang mempelajari rancangan dari kondisi fisiknya. Metode yang digunakan pada penelitian ini adalah deskriptif kualitatif. Permukiman pada area studi memiliki pola ruang tersebar yang disebabkan oleh kondisi relief wilayah berkontur. Rancangan dari kondisi fisik permukiman juga berbeda dengan wilayah lainnya. Rancangan kondisi fisik dari pola permukiman yang ada di lokasi studi belum banyak mendukung Situs Giri Kedaton untuk menjadi kawasan khusus yang memiliki nilai historis. Sehingga perlu adanya pengembangan permukiman dan peran serta masyarakat dalam menunjang keberadaan Situs Giri Kedaton.
\end{abstract}

Keywords: Pola Permukiman, Situs Giri Kedaton, Kabupaten Gresik

\begin{abstract}
The Giri Kedaton site is one of the historical value attractions in Gresik Districts. But its existence is less well known by tourists. One of the causes is the lack of carrying capacity of settlements around the Giri Kedaton Site, which is able to support the historical value of the region. So it is necessary to do this research to find out the settlement design patterns, that study the design of their physical condition. The method used in this study is qualitative descriptive method. Settlements in the study area have scattered spatial patterns caused by the relief conditions of contoured areas. The design of the physical conditions of the settlement is also different from other regions. The design of the physical conditions of the settlement has not supported the Giri Kedaton Site to become a special area that has historical value. So it is necessary to develop settlements and community participation in supporting the existence of the Giri Kedaton Site.
\end{abstract}

Keywords: Settlement Design Pattern, Giri Kedaton Site, Gresik Districts.

\section{PENDAHULUAN}

Pada abad ke-14, Situs Giri Kedaton merupakan pesantren atau tempat perguruan yang didirikan oleh Sunan Giri Santri yang belajar disana datang dari segala penjuru, bukan hanya dari kalangan bangsawan, tetapi juga dari kalangan rakyat kecil. Giri Kedaton merupakan salah satu peninggalan sejarah Islam di Kabupaten Gresik, dimana sistem pemerintahan Kota Gresik terbentuk disini. Gresik Kota menjadi pusat 
perdagangan. Sedangkan Giri, tepatnya Giri Kedaton menjadi pusat pemerintahan (Widodo, 2004).

Situs Giri Kedaton merupakan salah satu kawasan bersejarah di Kabupaten Gresik. Akan tetapi keberadaannya kurang dikenal. Salah satu penyebabnya adalah kurangnya daya dukung permukiman disekitar Situs Giri Kedaton yang mampu mendukung nilai historis Kawasan (Saputra, 2015). Sehingga perlu dilakukan penelitian ini untuk mengetahui pola permukiman yang mempelajari rancangan dari kondisi fisiknya.

\section{Tinjauan Teori}

Pola merupakan susunan atau tatanan yang menunjukkan hubungan antar unsur. Jika dikaitkan dengan permukiman, pola permukiman mempelajari rancangan dari kondisi fisiknya (Alexander, 1977). Pola ruang permukiman (Rifa'i, 2010) dibedakan menjadi 3 jenis, yaitu pola memusat, pola memanjang, dan pola menyebar yang tidak mengikuti pola tertentu. Sedangkan menurut Jayadinata dalam Pradnyana (2018), pola ruang permukiman dibagi menjadi 2 bagian besar, yaitu pola permukiman memusat dan terpecar.

Dalam perkembangannya, terdapat banyak faktor yang memengaruhi pola permukiman. Menurut Doxiadis (1968), terdapat lima aspek yang berpengaruh yaitu Nature (kondisi alam), Man (kondisi manusia), Society (sosial masyarakat), Shell (ruang berlindung) dan Network (jaringan penghubung). Sedangkan menurut Turgut dalam Pradnyana (2018), latar pembentuk pola ruang permukiman adalah setting spasial, perilaku, budaya, dan sosial ekonomi.

Tabel 1. Sintesa Tinjauan Teori

\begin{tabular}{ccl}
\hline No & Rumusan Teori & \multicolumn{1}{c}{ Pembahasan } \\
\hline 1 & Pola Ruang & - Pola memusat \\
& Permukiman & - Pola memanjang \\
& & - Pola menyebar yang \\
& & tidak mengikuti pola \\
& & tertentu \\
\hline 2 & Faktor yang & - Kondisi Alam \\
& memengaruhi pola & - Hunian \\
& permukiman & - Jaringan \\
& & Penghubung/Akses \\
& & Pencapaian \\
& & - Kondisi Manusia \\
& & - Sosial Masyarakat \\
& & - Budaya \\
& & - Ekonomi \\
&
\end{tabular}

Sumber: Penulis, 2018

\section{METODE PENELITIAN}

Metode yang digunakan pada penelitian ini adalah deskriptif kualitatif yang menguraikan fenomena dan fakta empiri dengan sistematis. Kemudian data dianalisa berdasarkan tinjauan teori yang dilakukan sebelumnya. Observasi terhadap studi kasus dan wawancara (in-depth interview) ditetapkan menjadi teknik pengumpulan data dalam penelitian ini.

\section{HASIL DAN PEMBAHASAN}

Giri Kedaton adalah warisan budaya peninggalan Sunan Giri yang terletak di Dusun Kedaton, Desa 
Sidomukti, Kabupaten Gresik. Saat ini situs berfungsi sebagai objek wisata dan bangunan cagar budaya yang telah dikonservasi pada tahun 2002. Giri Kedaton yang menjadi salah satu daya tarik pariwisata religi di Gresik.

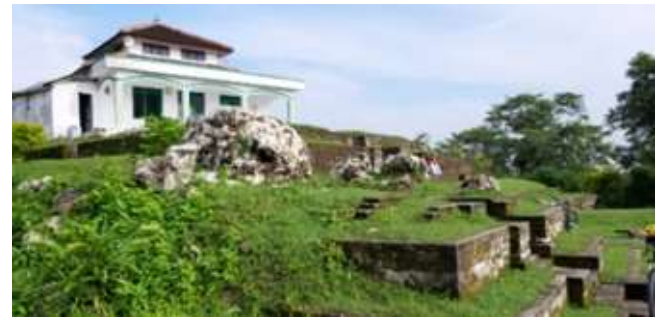

Gambar 1. Kondisi Eksisting Giri Kedaton (Sumber: Dokumentasi Pribadi, 2018)

Menurut Pengelola Situs Giri Kedaton, jumlah wisatawan yang datang tidak tentu. Biasanya dalam sehari, hanya ada \pm 10 orang wisatawan yang datang berkunjung. Jenis wisatawan yang datang berasal dari wilayah Gresik, wisatawan dalam negeri maupun luar negeri. Wisatawan berkunjung kesana dengan tujuan tertentu, misalnya berolahraga, sholat, bertapa, melakukan penelitian, dll.

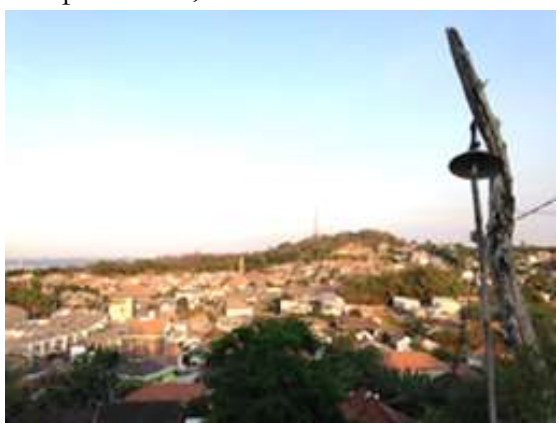

Gambar 2. View dari Giri Kedaton (Sumber : Dokumentasi Pribadi, 2018)
Banyak wisatawan terkesan dengan pemandangan yang ada pada kawasan ini. Hal tersebut menjadi salah satu keunggulan dari Situs Giri Kedaton. Selain udara yang sejuk, wisatawan juga dapat melihat hamparan pemandangan indah Kota Gresik dari ketinggian 200 mdpl.

Adanya Situs Giri Kedaton tidak banyak berdampak terhadap permukiman setempat. Kepekaan masyarakat terhadap potensi Situs juga masih rendah. Permukiman di sekitar Giri Kedaton menjadi studi kasus penelitian ini. Hal ini dilakukan untuk mengetahui pola permukiman guna mempelajari rancangan dari kondisi fisiknya. Deliniasi wilayah penelitian (Gambar 3) mencakup permukiman pada Jalan Sunan Giri (sisi utara), Jalan Sunan Giri Gang 13 (sisi timur), Jalan Sunan Giri Gang 15 (sisi barat), dan Jalan Sunan Giri Gang $13 \mathrm{~K}$ (sisi selatan).

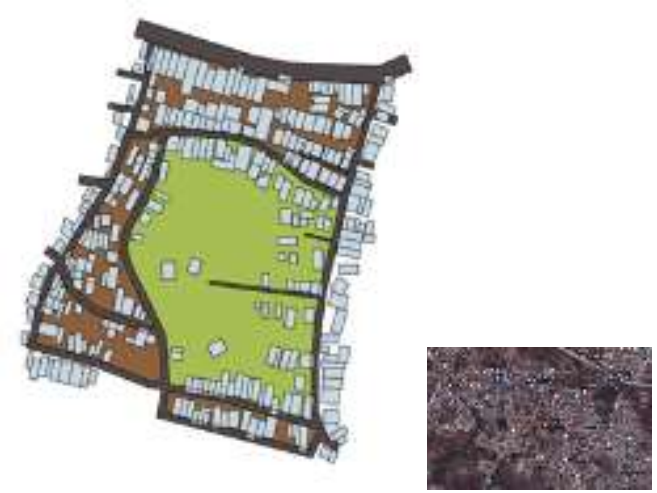

Gambar 3. Deliniasi Wilayah Penelitian

(Sumber : Dokumentasi Pribadi Diolah dari Google Maps, 2018) 


\section{Identifikasi Pola Ruang Permukiman}

Berdasarkan hasil observasi di lapangan, pola ruang permukiman yang ada di sekitar wilayah studi merupakan tipe pola menyebar, dimana tidak mengikuti pola tertentu. Perkembangan pola ini terjadi berpencaran secara sporadis dan tumbuh di sekeliling Situs Giri Kedaton.

\section{Identifikasi Faktor Pembentuk Pola Permukiman}

- Kondisi Alam (Nature)

Pola ruang permukiman yang ada di sekitar wilayah studi merupakan pola menyebar. Hal ini dipengaruhi oleh relief wilayah permukiman yang berkontur akibat kondisi alam perbukitan. Kesuburan tanah yang ada masih belum banyak dikelola dan dimanfaatkan dengan baik, padahal hal tersebut bisa menjadi sebuah potensi yang dapat dikembangkan oleh penduduk setempat. Kabupaten Gresik tergolong wilayah yang beriklim tropis, sehingga bentukan rumah menyesuaikan dengan kondisi iklim yang ada. Mayoritas jenis atap yang banyak digunakan di Desa Sidomukti adalah atap pelana, karena sangat tahan terhadap cuaca di iklim tropis.

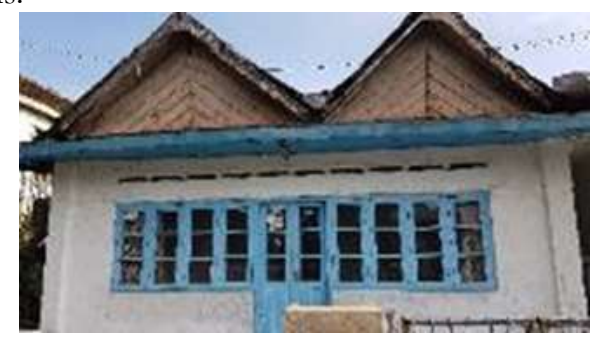

Gambar 4. Atap Pelana Banyak Digunakan (Sumber : Dokumentasi Pribadi, 2018)
- Hunian

Material dinding yang banyak digunakan adalah batu bata. Sedangkan untuk material penutup atap, banyak penduduk menggunakan genteng dan asbes. Asbes banyak digunakan warga, karena harganya murah dan terjangkau. Walaupun cukup beresiko bagi kesehatan penghuninya.

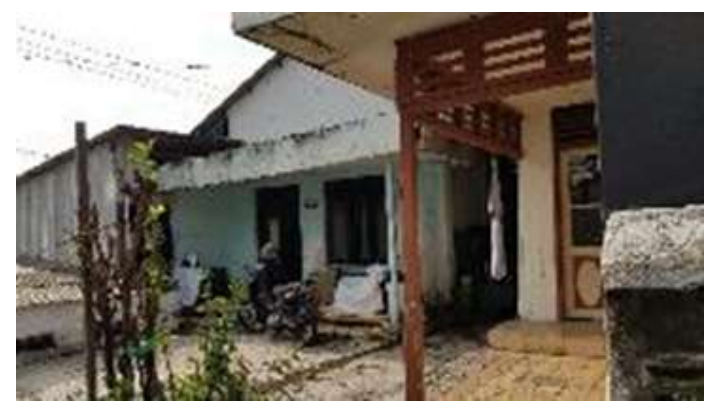

Gambar 5. Asbes Menjadi Salah Satu Alternatif Material yang Banyak Digunakan sebagai Penutup Atap (Sumber : Dokumentasi Pribadi, 2018)

Rumah-rumah yang ada pada wilayah studi diidentifikasikan berdasarkan dengan jenis jalan yang ada. Adapun hasil identifikasi dapat dilihat pada tabel 2.

Tabel 2. Identifikasi Rumah

\begin{tabular}{|c|c|c|}
\hline No & Jalan & Identifikasi \\
\hline 1 & $\begin{array}{l}\text { Jl. Sunan Giri } \\
\text { (Jalan Raya) }\end{array}$ & $\begin{array}{l}\text { Mix-used antara fungsi hunian } \\
\text { dengan fungsi usaha. Jenis } \\
\text { usaha yang mendominasi } \\
\text { adalah warung makanan dan } \\
\text { kios. }\end{array}$ \\
\hline 2 & $\begin{array}{l}\text { Jl. Sunan Giri } \\
\text { gg. XIII, XIII H }\end{array}$ & $\begin{array}{l}\text { - Beberapa rumah mulai } \\
\text { mengembangkan industri }\end{array}$ \\
\hline
\end{tabular}




\begin{tabular}{|c|c|c|}
\hline & $\begin{array}{c}\text { dan XV } \\
\text { (Akses Jalan } \\
\text { Utama dari } \\
\text { Permukiman } \\
\text { Menuju Situs) }\end{array}$ & $\begin{array}{l}\text { rumah tangga. } \\
\text { - Mulai banyak rumah yang } \\
\text { menggunakan pagar, } \\
\text { mengingat banyaknya } \\
\text { penduduk yang mulai } \\
\text { membutuhkan privasi. } \\
\text { - Luas lahan lebih besar, } \\
\text { sehingga memiliki } \\
\text { halaman yang cukup lebar. } \\
\text { - Merupakan akses jalan } \\
\text { utama dari permukiman } \\
\text { menuju ke Situs, namun } \\
\text { belum ditemukannya ciri } \\
\text { khas yang mencerminkan } \\
\text { nilai historis Kawasan. }\end{array}$ \\
\hline 3 & $\begin{array}{c}\text { Jl. Sunan Giri } \\
\text { gg. XIII E, F, G, } \\
\text { H, K, M } \\
\text { (Gang Kecil } \\
\text { Penunjang) }\end{array}$ & $\begin{array}{l}\text { - Pada Jl. Sunan Giri gg. } \\
\text { XIII M, terdapat rumah } \\
\text { (bangunan cagar budaya) } \\
\text { yang dengan gaya } \\
\text { arsitektur kolonial. Akan } \\
\text { tetapi kondisinya saat ini } \\
\text { rusak dan tidak terawat. } \\
\text { - Mayoritas ukuran lahan } \\
\text { kecil, sehingga tidak } \\
\text { memiliki halaman } \\
\text { (langsung teras). } \\
\text { - Rumah penduduk jarang } \\
\text { yang menggunakan pagar. } \\
\text { - Beberapa rumah mulai } \\
\text { mengembangkan industri } \\
\text { rumah tangga }\end{array}$ \\
\hline
\end{tabular}

Sumber : Penulis, 2018

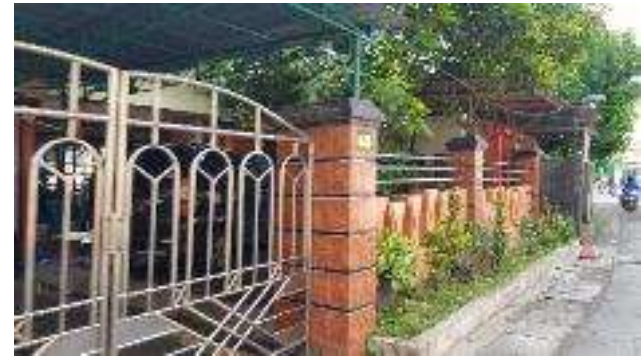

Gambar 6. Penambahan Elemen Pagar pada Salah Satu Hunian di J1. Sunan Giri gg. XIII

(Sumber : Dokumentasi Pribadi, 2019)

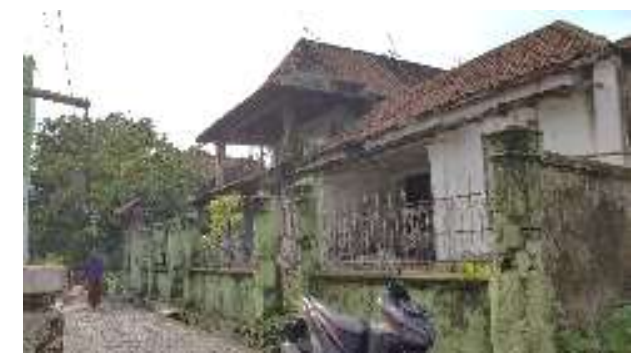

Gambar 7. Salah Satu Rumah dengan Gaya Arsitektur Kolonial

(Sumber: Dokumentasi Pribadi, 2018)

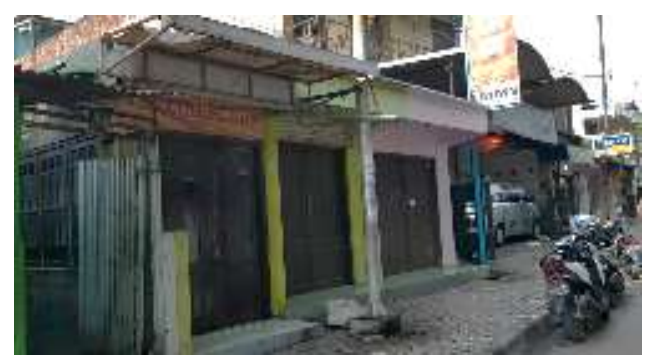

Gambar 8. Fungsi Mix-used pada Hunian yang ada di J1. Sunan Giri

(Sumber : Dokumentasi Pribadi, 2018) 
- Jaringan Penghubung / Akses Pencapaian Akses pencapaian Situs Giri Kedaton dengan permukiman penduduk dapat dijangkau melalui Jl. Sunan Giri gg. XIII H. Untuk mencapai Situs, pengunjung harus menaiki tangga (Gambar 9). Akan tetapi kondisi dari railing tangga kurang laik dan membahayakan wisatawan.

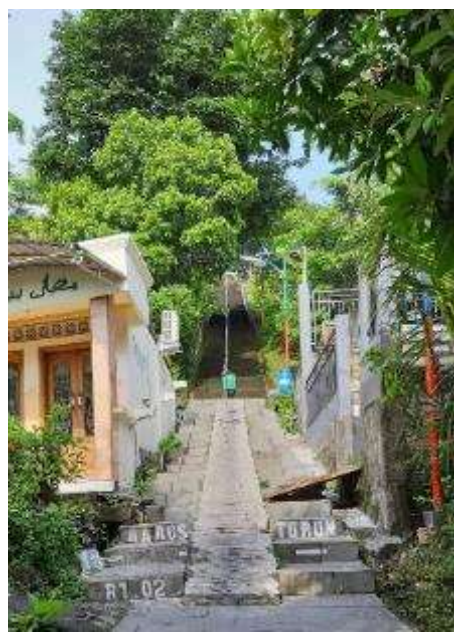

\section{Gambar 9. Tangga Menuju Ke Situs Giri Kedaton}

(Sumber : Dokumentasi Pribadi, 2018)

Berdasarkan hasil observasi di lapangan, mulai ada keinginan dari penduduk setempat untuk mendukung dan menunjang keberadaan Situs Giri Kedaton. Halaman rumah penduduk pada Jl. Sunan Giri gg. XIII H banyak yang dialihfungsikan sebagai tempat parkir motor wisatawan (Gambar 10). Akan tetapi yang menjadi permasalahan disini adalah kurangnya lahan parkir untuk kendaraan roda empat. Para pengunjung yang membawa mobil harus memarkir kendaraannya di pinggir Jl. Sunan Giri gg. XIII. Hal ini menimbulkan kemacetan lalu lintas jalan perkampungan.

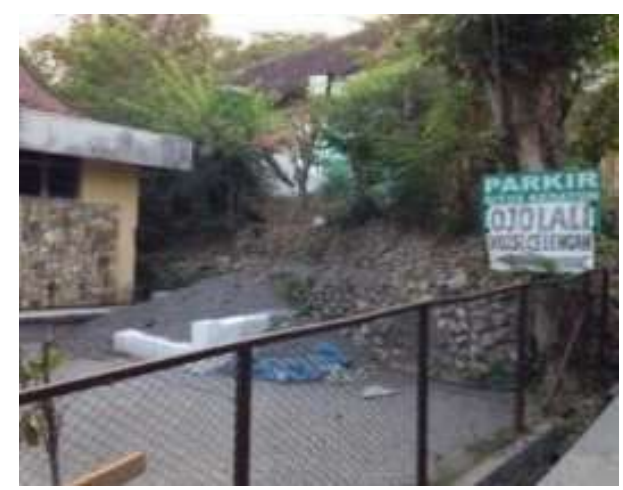

\section{Gambar 10. Parkir Motor yang Disediakan Penduduk}

(Sumber : Dokumentasi Pribadi, 2018)

\section{- Sosial Masyarakat}

Sosial masyarakat pada area studi memiliki nilai kekeluargaan yang sangat tinggi. Hal ini disebabkan antar tetangga masih memiliki hubungan kekerabatan. Mayoritas rumah penduduk tidak berpagar. Antar tetangga saling percaya bahwa tidak mungkin mereka menyakiti dan berbuat jahat, karena masih ada hubungan keluarga. 


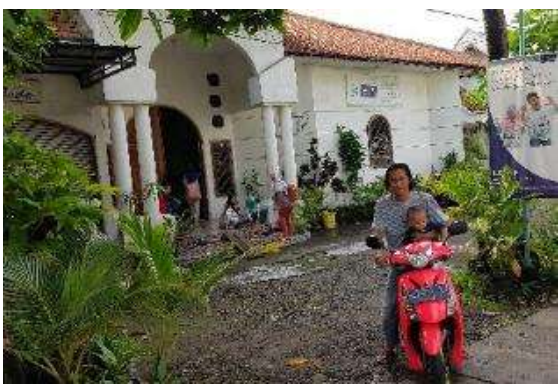

Gambar 11. Rumah Tanpa Pagar

(Sumber: Dokumentasi Pribadi, 2018)

\section{- Budaya}

Kegiatan rutin tahunan yang diselenggarakan oleh Pemerintahan Kabupaten Gresik di Giri Kedaton adalah Kirab Budaya. Kegiatan ini dilakukan guna memperingati hari jadi Kota Gresik dan penobatan Sunan Giri sebagai Raja di Giri. Kirab diawali dari Giri Kedaton dan diakhiri di Alun - Alun Gresik. Kegiatan ini menyebabkan kemacetan, akibat keterbatasan lahan parkir. Sehingga para peserta Kirab harus memarkir kendaraannya di pinggir jalan perkampungan.

Aspek dari kekuatan religi dapat membentuk perilaku manusia. Penduduk yang ada disana sangat memegang teguh budaya islam, banyak acara keagamaan yang dilakukan penduduk setempat seperti yasinan, tadarusan, diba'an, dll. Agama juga memengaruhi pola ruang permukiman pada wilayah studi, dimana tiap 50-100 meter terdapat langgar atau mushola. Hal ini disebabkan penduduk setempat memiliki kebiasaan shalat secara berjamaah. Masyarakat percaya bahwa shalat berjamaah akan lebih besar pahalanya jika dilaksanakan di Masjid/Mushola/Langgar.

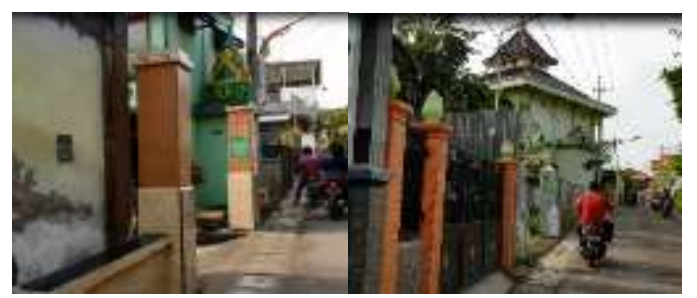

Gambar 12. Langgar dan Mushola di Jl. Sunan Giri gg XIII

(Sumber: Dokumentasi Pribadi, 2018)

\section{- Ekonomi}

Keberadaan Situs Giri Kedaton tidak banyak memberikan kontribusi ekonomi bagi penduduk. Namun beberapa penduduk secara tidak langsung mulai sadar akan Potensi Situs Giri Kedaton dalam meningkatkan nilai ekonomi. Karena keterbatasan fasilitas perparkiran, penduduk mulai mengalihfungsikan halaman rumahnya sebagai lahan parkir wisatawan.

Penduduk Dusun Kedaton lebih banyak menjalankan usaha di bidang industri rumah tangga, seperti kerajinan kemasan/imitasi, krupuk dadur (puli), manisan buah, warung makanan, kios, dll. Usaha ini digeluti oleh penduduk yang berusia $40-$ 50 tahun. Sedangkan penduduk berusia $20-30$ tahun banyak yang lebih memilih untuk bekerja 
sebagai buruh, karyawan, maupun Pegawai Negeri Sipil.

Seiring berjalannya waktu dan tumbuhnya nilai ekonomi di wilayah studi, menyebabkan penduduk mulai banyak yang merenovasi rumahnya. Mereka memiliki kecenderungan untuk meningkat rumahnya menjadi 2 lantai, karena keterbatasan ruang. Selain itu beberapa penduduk mulai menggunakan rumahnya untuk meningkatkan nilai ekonomi pemiliknya, dengan cara membuka warung atau kios. Dalam merenovasi rumah, mereka mulai menambahkan elemen pagar sebagai upaya pengamanan dan meningkatkan privasi penghuninya.

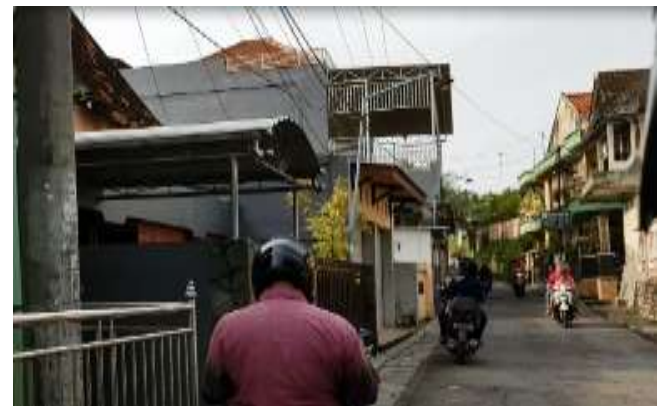

Gambar 13. Salah Satu Rumah Bertingkat 2 di J1. Sunan Giri gg. XIII

(Sumber: Dokumentasi Pribadi, 2018)

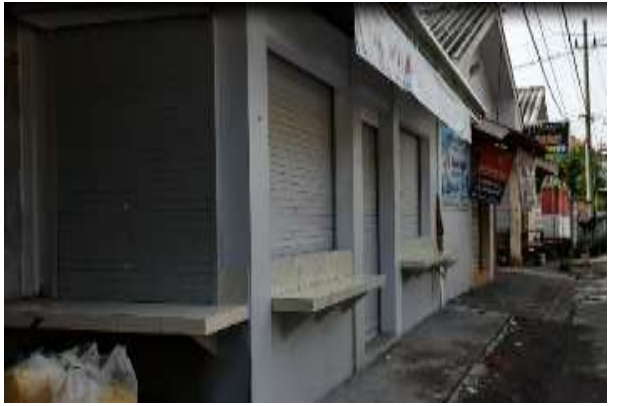

Gambar 14. Penambahan Ruang Usaha pada Hunian

(Sumber : Dokumentasi Pribadi, 2018)

\section{SIMPULAN}

Permukiman pada area studi memiliki pola ruang tersebar yang disebabkan oleh kondisi relief wilayah berkontur. Rancangan dari kondisi fisik permukiman juga berbeda dengan wilayah lainnya. Bentukan rumah menyesuaikan dengan kondisi lingkungan. Budaya dari Agama Islam turut serta dalam memengaruhi pola ruang permukiman pada wilayah studi. Sosial masyarakat pada area studi memiliki nilai kekeluargaan yang sangat tinggi. Namun seiring berjalannya waktu dan tumbuhnya nilai ekonomi di wilayah studi, menyebabkan adanya perubahan bentuk rumah yang disesuaikan dengan kebutuhan dan keinginan penghuni.

Pada area studi terdapat banyak potensi yang dapat dikembangkan dalam mendukung Situs Giri Kedaton menjadi kawasan khusus bernilai historis, seperti adanya industri rumah tangga, lahan hijau yang belum terolah, rumah yang tergolong bangunan cagar budaya dan fasilitas perparkiran. Sedangkan permasalahan yang 
perlu diatasi adalah kepedulian dan kepekaan penduduk terhadap Situs Giri Kedaton. Pemerintahan Kabupaten Gresik sudah mulai menyelenggarakan kegiatan rutin tahunan yang secara tidak langsung membuat penduduk setempat mulai sadar terhadap Potensi Situs Giri Kedaton dalam meningkatkan nilai ekonomi.

Rancangan kondisi fisik dari pola permukiman yang ada di lokasi studi belum banyak mendukung Situs Giri Kedaton untuk menjadi kawasan khusus yang memiliki nilai historis. Sehingga nantinya perlu ada pengembangan permukiman dan peran serta masyarakat dalam menunjang keberadaan Situs Giri Kedaton.

\section{REFERENSI}

Widodo, Dukut Imam. Grissee Tempo Doeloe. Gresik: Pemerintahan Kabupaten Gresik, 2004.

Saputra, dkk, 2015. Vitality of Giri Kedaton Site as a Religious Tourism Attraction in Sidomukti Village, Kebomas, Gresik. Journal of Indonesian Tourism and Development Studies, Vol. 3, No. 3, $93-104$.

Alexander, C., (1977). Pattern Language, Oxford University Press, New York.

Rifa'i. 2010. Analisis Perkembangan Fisik Kota Palu dengan Citra Landsat. Jurnal Ruang, 3, 1, 4654.

Pradnyana, dkk, 2018. Faktor Pembentuk Pola Ruang Permukiman Tradisional Bali Aga Pada Desa Adat Bugbug, Karangasem, Bali. Skripsi. Universitas Brawijaya.
Doxiadis, C. A.,1968. Ekistic, An Introduction to the Science of Human Settlements. London: Hutchinson of London. 